\title{
SPONCER (SMART POND CONTROLLER) PENGENDALI LINGKUNGAN AIR KOLAM GUNA OPTIMALISASI PRODUKSI IKAN SIDAT DI BUDI FISH FARM, NGAGLIK, SLEMAN, DAERAH ISTIMEWA YOGYAKARTA
}

\author{
Naufal Kurnia Sandy ${ }^{1}$, Wahyu Romadhoni ${ }^{2}$, Taufan Putera Pamungkas ${ }^{3}$, Annisa Nur Hayati ${ }^{4}$, \\ Natallensi Deara Cheardi ${ }^{5}$ \\ ${ }^{1,2,3}$ Pendidikan Teknik Mekatronika FT UNY, ${ }^{4}$ Pendidikan Kimia FMIPA UNY, ${ }^{5}$ Biologi FMIPA UNY ${ }^{5}$ \\ email : naufal.kurnia2016@ student.uny.ac.id
}

\begin{abstract}
Eel (Anguilla sp.) is one of the best-selling fish in international markets such as Japan, Hong Kong, Germany, Italy and several other countries. For example, in Japan, which has as much as 600 tons of eel needs every month, while Indonesia is only able to meet eel needs of 500 tons per month. Eel is susceptible to water environment conditions such as temperature and $\mathrm{pH}$. Eel has ideal conditions, namely $27{ }^{\circ} \mathrm{C}-29{ }^{\circ} \mathrm{Cand}$ pH 6-9. Inappropriate conditions will trigger death. SPONCER is an intelligent eel fish technology investment equipped with temperature sensors, $p H$ sensors, arduino, photovoltaic cells, and water filters that function to maintain optimal temperature and $\mathrm{pH}$ for eel fish life automatically. SPONCER can reduce eel mortality by $57.14 \%$ so that it can contribute to increasing eel productivity in the international market.
\end{abstract}

Keywords : Anguilla sp., Innovation, Automation

\begin{abstract}
ABSTRAK
Ikan sidat (Anguilla sp.) merupakan salah satu ikan yang sangat laku di pasar Internasional seperti Jepang, Hongkong, Jerman, Italia dan beberapa negara lain. Contohnya pada negara Jepang yang memiliki kebutuhan ikan sidat sebanyak 600 ton tiap bulan, sedangkan Indonesia hanya mampu memenuhi kebutuhan ikan sidat sebesar 500 ton tiap bulan. Ikan sidat rentan terhadap kondisi lingkungan air seperti suhu dan pH. Ikan sidat memiliki kondisi yang ideal yaitu $27^{\circ} \mathrm{C}-29^{\circ} \mathrm{C}$ dan $\mathrm{pH}$ 6-9. Kondisi yang tidak sesuai akan memicu kematian. SPONCER adalah invoasi teknologi kolam ikan sidat cerdas yang dilengkapi dengan sensor suhu, sensor $\mathrm{pH}$, arduino, sel photovoltaic, dan filter air yang berfungsi untuk menjaga suhu dan $\mathrm{pH}$ yang optimal bagi kehidupan ikan sidat secara otomatis. SPONCER dapat menurunkan kematian ikan sidat sebesar 57,14\% sehingga dapat berkontribusi dalam peningkatan produktivitas ikan sidat di pasar Internasional.
\end{abstract}

Kata kunci: Anguilla sp.,Inovasi, Ototomatis

\section{PENDAHULUAN}

Indonesia merupakan negara kepulauan dengan luas wilayah laut yang mencapai $3.287 .010 \mathrm{~km}^{2}$ atau sekitar $62 \%$ dari seluruh wilayah Indonesia. Luas laut yang besar ini menjadikan Indonesia unggul dalam sektor perikanan dan kelautan (Nontji, 2005). Keunggulan dibidang perikanan dan kelautan Indonesia salah satunya adalah budidaya ikan sidat. Ikan sidat (Anguilla sp.) merupakan ikan yang laku di pasar internasional seperti Jepang,
Hongkong, Jerman, Italia dan beberapa negara lain, dengan demikian ikan ini memiliki potensi sebagai komoditas ekspor. Peluang pasar yang begitu besar tersebut juga diakui oleh Direktur Pemasaran Luar Negeri Kementerian Kelautan dan Perikanan, potensi ekspor ikan sidat terutama ke negara-negara tersebut harus dipertahankan. Setiap tahun permintaan ikan sidat dari Negara Jepang sendiri mencapai 600 ton per bulan sedangkan Negara Indonesia hanya mampu memenuhi 500 ton ikan sidat per 
bulan. Harga ikan sidat (Anguilla sp.) pun menggiurkan contohnya jenis ikan sidat (Anguilla sp.) bicolor dihargai $\mathrm{Rp}$ 60.000-Rp 70.000 per $\mathrm{kg}$, sedangkan harga sekilo ikan sidat (Anguilla sp.) Marmorata di Jakarta bisa mencapai Rp 900 ribu (isi 6.000 ekor), dan ikan sidat (Anguilla sp.) Elver Rp 550 ribu (isi 100 ekor) (Affandi, R. 2001).

Budi Fish Farm merupakan salah satu tempat budidaya dengan memiliki berbagai macam jenis ikan termasuk ikan sidat di Daerah Istimewa Yogyakarta. Permasalahan utama yang dialami adalah banyak ikan sidat yang terjangkit penyakit karena kekurangan suplai oksigen saat proses budidaya, tidak konstannya suhu air kolam dan kotornya air di kolam sehingga hasil produksi ikan sidat belum maksimal. Kadar Oksigen dalam air (Dissolved Oxygen), suhu air, dan kebersihan air merupakan komponen penting yang dibutuhkan oleh ikan sidat dan sangat berpengaruh terhadap kuantitas dan kualitas hasil panen. Upaya yang dilakukan oleh Budi Fish Farm adalah menggunakan sistem tambah kurang air dimana kolam selalu diisi air bersih dengan model air terjun dan mengurangi air yang melebihi ambang batas ketinggian air kolam sekaligus berfungsi sebagai pengatur suhu air. Sistem ini dipandang kurang efektif karena hanya membuang air yang melebihi ambang batas ketinggian air sedangkan endapan kotoran dan bekas pakan ikan tidak ikut terbuang sehingga kualitas hasil panen belum maksimal. Suhu air kolam juga tidak terlalu terkontrol dengan sistem tersebut karena suhu air kolam sebenarnya mengikuti suhu lingkungannya, saat malam hari suhu lingkungan turun maka akan mempengaruhi suhu air kolam sehingga suhunya turun dan sebaliknya. Menurut Sutrisno (2008), suhu ideal bagi ikan sidat adalah $27^{\circ} \mathrm{C}-29^{\circ} \mathrm{C}$ dan salinitas sebesar 5 ppt. Menurut Affandi dan Suhenda (2003), kadar pH yang ideal bagi ikan sidat adalah $6 \mathrm{pH}-9 \mathrm{pH}$ dan kadar amoniak sebesar $<0,1 \mathrm{mg} / \mathrm{l}$. Menurut Yudiarto et al (2012), kadar oksigen dalam air
(Dissolved Oxygen) adalah sebesar $4 \mathrm{mg} / \mathrm{l}-8$ $\mathrm{mg} / \mathrm{l}$.

Oleh karena itu solusi yang ditawarkan untuk mengatasi permasalahan di Budi Fish Farm adalah dengan SPONCER (Smart Pond Controller) yang merupakan inovasi teknologi kolam ikan cerdas menggunakan sensor suhu, sensor $\mathrm{pH}$ sebagai sensornya dan Arduino sebagai pengontrolnya. Sistem airasi, sirkulasi air sebagai penggeraknya serta sel photovoltaic sebagai sumber tenaga listriknya. Menurut Hickling (1971) dalam Mukti dkk., (2003), oksigen terlarut merupakan parameter kunci kualitas air. Tersedianya oksigen terlarut dalam air sangat menentukan kehidupan ikan, kadar oksigen yang rendah dapat berpengaruh terhadap fungsi dan lambatnya pertumbuhan bahkan dapat mengakibatkan kematian pada ikan (Mahasri, 2006). Kelebihan SPONCER (Smart Pond Controller) ini adalah mampu menjaga suhu dan $\mathrm{pH}$ yang ideal bagi kehidupan ikan sidat secara otomatis, dapat menyirkulasi air kolam yang kotor menjadi bersih tanpa harus diganti air baru, dan menambah sumber energi cadangan dengan sel photovoltaic, sehingga pengelola kolam budidaya dapat dengan mudah memantau kualitas air serta menghemat biaya operasional listrik dan dapat meingkatkan kualitas dan kuantitas hasil produksi ikan sidat.

\section{METODE}

SPONCER terdiri dari sel photovoltaic, MPPT, Aki, Inverter, Pompa Air, Aerator, Arduino dan Heater.

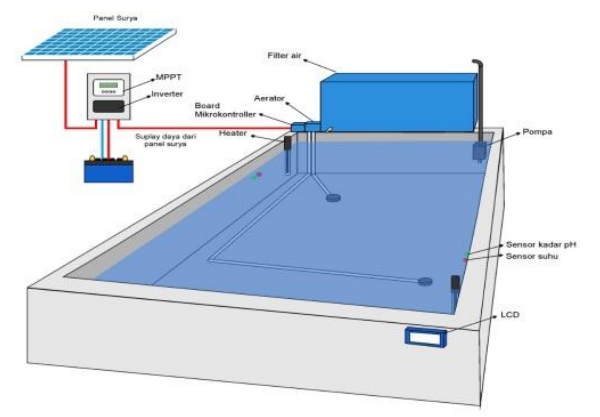

Gambar 1. Detail lengkap dari SPONCER. (Dokumentasi Pribadi) 
Sinar matahari akan masuk ke dalam sel photovoltaic, sel photovoltaic berfungsi untuk mengkonversi energi cahaya menjadi energi listrik berupa arus DC. Invensi ini memiliki perbedaan cara kerja pada siang hari dan malam hari sebagai berikut: Pada siang hari, tegangan listrik dari sel photovoltaic akan masuk ke dalam MPPT, dimana MPPT berfungsi untuk mengontrol arus listrik dari sel photovoltaic ke aki dan inverter. Tegangan listrik yang masuk ke inverter akan diubah menjadi arus AC yang selanjutnya akan dialirkan pada komponen pompa air, aerator, arduino dan heater. Sedangkan pada malam hari, tegangan listrik dari aki akan masuk ke dalam MPPT untuk diubah menjadi arus AC dalam inverter dan selanjutnya dialirkan pada komponen pompa air, aerator, arduino dan heater.

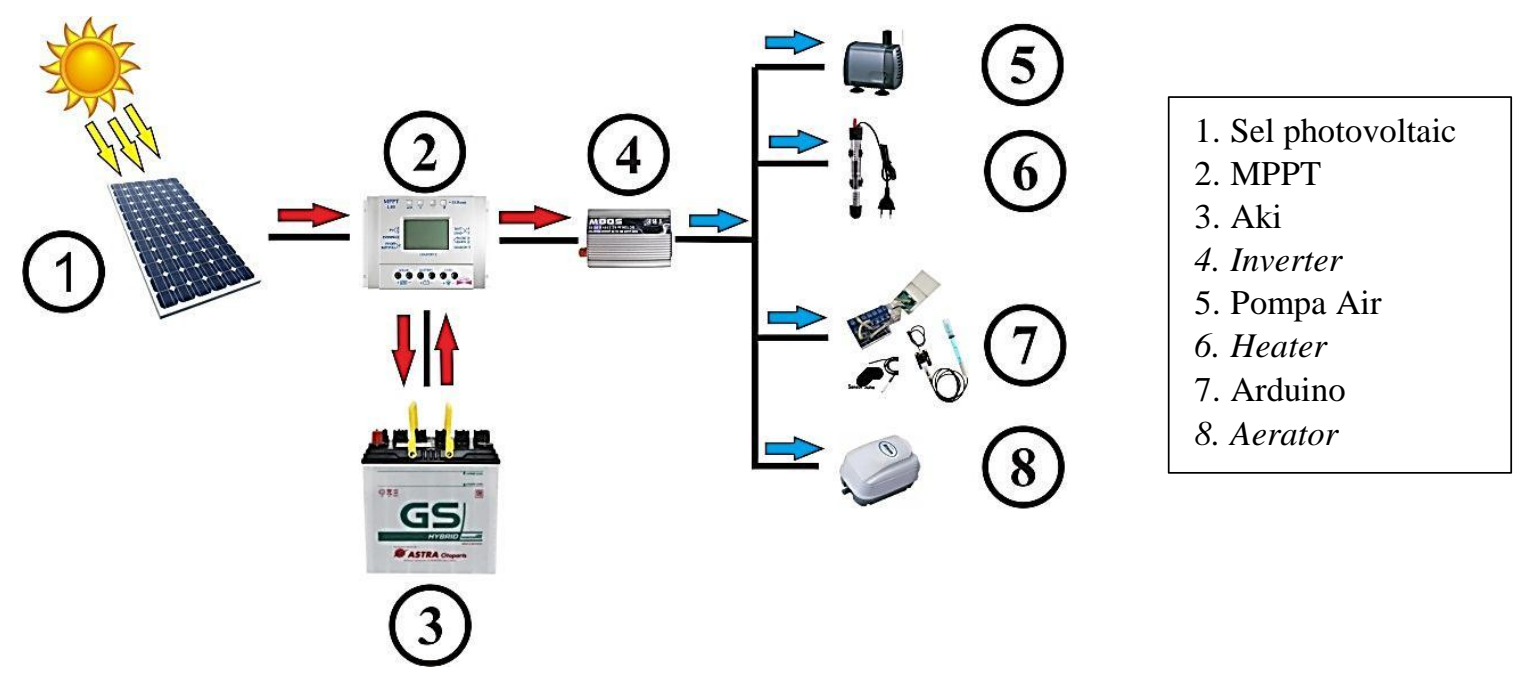

Gambar 2. Cara kerja aliran listrik dari sumber ke komponen-komponen.

(Dokumentasi Pribadi)

SPONCER dilengkapi dengan sensor suhu dan $\mathrm{pH}$ yang dapat mendeteksi kondisi lingkungan pada air kolam berupa suhu dan $\mathrm{pH}$. Cara kerja sensor adalah apabila sensor suhu mendeteksi suhu dibawah $27{ }^{\circ} \mathrm{C}$, maka heater akan hidup hingga suhu sesuai dengan suhu optimal bagi kehidupan ikan sidat,

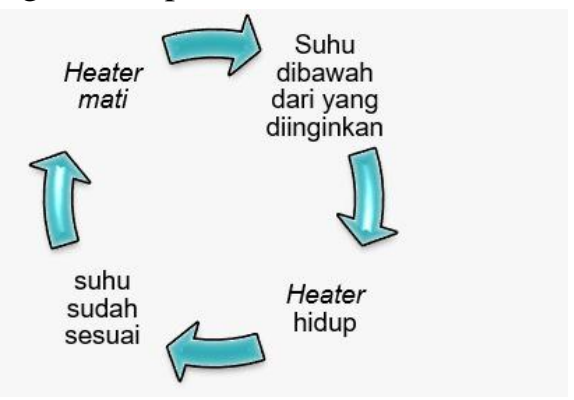

Gambar 3. Cara kerja sensor suhu. (Dokumentasi Pribadi)

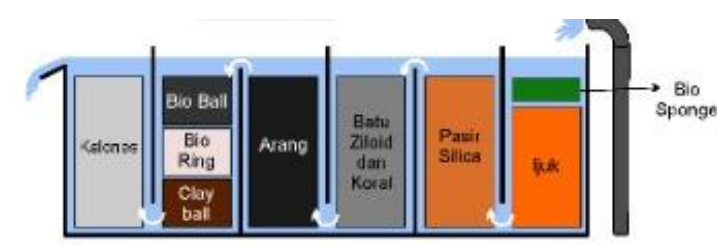

Gambar 4. Gambar detail dari filter. (Dokumentasi Pribadi)

Filter air menggunakan bahan dari segi mekanik berupa ijuk, dan pasir silica yang berfungsi untuk menyaring kotoran melalui pori-pori, segi kimia berupa batu ziloid, koral dan arang aktif yang berfungsi untuk mengikat ion-ion yang berbahaya dan segi biologi berupa clay ball, bio ring, bio ball dan kaldness yang berfungsi sebagai tempat bakteri baik untuk mengurai amoniak.

Metode pelaksanaan dilakukan di Budi Fish Farm yang merupakan salah satu badan usaha yang bergerak dibidang pembesaran ikan 
sidat yang berada di Ngaglik, Sleman, Daerah Istimewa Yogyakarta. Pelaksaan dilakukan selama 1 bulan pada sampel ikan sidat berumur 2 bulan. Semua alat dipasang dan dinyalakan, maka SPONCER akan bekerja secara otomatis untuk menjaga dan mempertahankan suhu serta pH yang sesuai dengan kondisi ideal ikan sidat. Pemantauan dapat dilakukan dengan melihat layar monitor berupa LCD yang berada dialat tersebut.

\section{HASIL DAN PEMBAHASAN}

Impementasi rancangan mendapatkan hasil bahwa terjadi penurunan kematian ikan sidat pada umur 2 bulan, dimana pada umur tersebut ikan sidat mengalami kondisi yang rentan terhadap kematian karena kualitas air. Menurut pemilik Budi Fish Farm, rata-rata kematian ikan sidat pada umur 2 bulan selama sebulan sebelum pemakaian alat adalah sebanyak 56 ekor ikan sidat, dengan data setiap minggunya seperti pada tabel.

Tabel 1. Data kematian ikan sidat pada umur 2 bulan sebelum pemakaian SPONCER

\begin{tabular}{|l|l|}
\hline Minggu Ke- & Jumlah kematian \\
\hline 1 & 20 \\
\hline 2 & 17 \\
\hline 3 & 11 \\
\hline 4 & 9 \\
\hline
\end{tabular}

Sedangkan, dari 1 bulan pelaksaan didapatkan hasil bahwa terjadi kematian ikan sidat sebanyak 24 ekor ikan sidat, dengan data setiap minggunya seperti pada tabel.

Tabel 2. Kematian Ikan sidat pada umur 2 bulan setelah pemakaian SPONCER

\begin{tabular}{|l|l|}
\hline Minggu Ke- & Jumlah kematian \\
\hline 1 & 8 \\
\hline 2 & 6 \\
\hline 3 & 6 \\
\hline 4 & 4 \\
\hline
\end{tabular}

Dari hasil data sebelum dan sesudah pemakaian alat, maka dapat dilihat bahwa terjadi penurunan kematian ikan sidat setelah penggunaan alat seperti pada tabel 2. Jika di presentasikan, maka terjadi penurunan kematian ikan sidat pada umur 2 bulan sebesar 57,14\%

Tabel 3. Grafik penurunan kematian ikan sidat setelah dan sesudah pemakaian alat

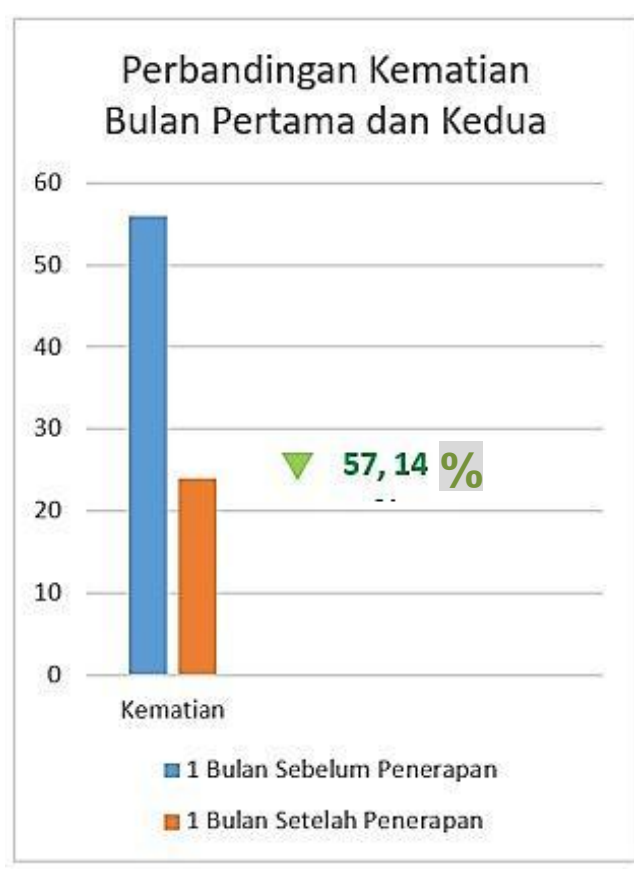

Penurunan kematian terjadi karena SPONCER mampu menjaga dan mempertahankan suhu dan $\mathrm{pH}$ yang sesuai dengan kondisi kehidupan sidat, yaitu pada suhu $27^{\circ} \mathrm{C}-29^{\circ} \mathrm{C}$ Sutrisno (2008) dan $\mathrm{pH} 6 \mathrm{pH}$ - 9 pH Suhenda (2003). Hal ini disebabkan karena sensor suhu dan $\mathrm{pH}$ dapat mendeteksi kondisi lingkungan air pada air kolam, sehingga pada saat kondisi lingkungan tidak ideal, maka sensor akan memperintah arduino untuk menghidupkan heater, filter serta aerator untuk membuat kondisi lingkungan air kolam sesuai dengan kondisi ideal. Selain karena suhu dan $\mathrm{pH}$, kadar amoniak juga berpengaruh pada kehidupam ikan sidat. Amoniak adalah salah satu senyawa yang berbahaya bagi kehidupan ikan sidat. Dengan adanya SPONCER yang dilengkapi dengan filter air yang yang terdiri dari mekanik, kimia dan biologi, kadar amoniak dapat diurai dengan filter dari bahan kimia dan biologi. Dari bahan kimia, dimana bahan tersebut akan mengikat senyawa amoniak yang bersifat polar. Kemudian amoniak juga dapat diurai melalalui bahan biologi, dimana bahan 
tersebut merupakan rumah bagi bakteri pengurai amoniak. Dalam hal ini akan terjadi denitrifikasi, dimana amoniak akan diubah menjadi nitrit oleh bakteri Nitrosomonas sp. Kemudian dari nitrit akan diubah menjadi nitrat oleh bakteri Nitrobacter $s p$. Menjadi senyawa yang tidak berbahaya.

\section{SIMPULAN}

SPONCER merupakan inovasi alat kolam ikan sidat cerdas yang dilengkapi sensor suhu, sensor $\mathrm{pH}$, arduino, sel photovoltaic dan filter air (terdiri dari mekanik, kimia dan biologi) berguna untuk menyaring kotoran, mengurai amoniak, menjaga dan mempertahan suhu serta $\mathrm{pH}$ yang optimal bagi kehidupan ikan sidat secara otomatis. Dengan pemakaian SPONCER terjadi penurunan kematian ikan sidat pada umur 2 bulan sebesar 57,14\%, dimana pada umur tersebut merupakan kondisi yang rentan bagi ikan sidat mengalami kematian.

\section{DAFTAR RUJUKAN}

Affandi, R. 2001. Budidaya ikan sidat. Fakultas Perikanan dan Ilmu Kelautan Institut Pertanian Bogor. hal.35

Affandi, R. 2005. Strategi Pemanfaatan Sumberdaya Ikan Sidat, (Anguilla sp.) di Indonesia. Jurnal Iktiologi Indonesia, Vol. 5(2). Hal $77-81$

Affandi, R.,B. Tatag, I.W. Ronny, dan T. Am Azbas. 2013. Pemeliharaan Ikan Sidat dengan Sistem Air Bersirkulasi.Jurnal Ilmu Pertanian Indonesia (JIPI). Vol 18(1) :55-80.

Affandi, R. dan Suhenda, N. 2003. Teknik Budidaya Ikan Sidat (Anguilla bicolor bicolor). Prosiding Sumberdaya Perikanan Sidat Tropik. Hlm. 47-54.

Hafidz, Abdul. 2015. Rancang Bangun Sistem Kontrol Akuarium Otomatis Berbasis Mikrokontroler. Universitas Nasional : Jakarta

Joves, Iriana. 2016. Analog $\mathrm{pH}$ meter kit. Diambil dari https://www.circuithelp.com.ph/product/analog-ph-meter-

kit/, diakses pada 24 Oktober 2017 pukul 10.17 WIB

Sasongko, A., dkk. 2007. Sidat. Jakarta : penebar Swadaya

Sutrisno. 2008. Penentuan Salinitas Air dan Jenis Pakan Alami yang Tepat dalam Pemeliharaan Benih Ikan Sidat (Anguilla bicolor). Jurnal Akuakultur Indonesia. 7 (1) : 71-77.

Yudiarto, Suryo, M. Arief, Agustono. 2012. Pengaruh Penambahan Atraktan yang Berbeda dalam Pakan Pasta terhadap Retensi Protein, Lemak dan Energi Benih Ikan Sidat (Anguilla bicolor) Stadia Elver. Jurnal Ilmiah Perikanan dan Kelautan. 4 (2) : 135-140. 